\title{
Structural and Elite Features in 三pen Seat and Special U.S. 䲶 House Elections: Is There a Sexual Bias?
}

RONALD KEITH GADDIE, UNIVERSITY OF OKLAHOMA CHARLES S. BULLOCK, III, UNIVERSITY OF GEORGIA

\begin{abstract}
Conventional wisdom long held that there was a bias against women in elections. Subsequent research indicates that men and women who challenge for elective office confront a common barrier: incumbency. In this article we extend our previous research on women in open seat elections by examining the performance of women who compete in special elections. Female candidate emergence in special House contests is slightly higher than in regular open seats. Using multivariate regression models, our analysis uncovered no bias against women in special elections. Overall, the performance of women in special elections and open seats indicates that disruptions of the political status quo by the sudden vacancy creates opportunities that women exploit with effectiveness, although the low level of female candidate emergence limits the growth of descriptive female representation.
\end{abstract}

A sustained argument in the debate over representation centers on the existence of sexual bias in congressional elections. Although some studies indicate an historical bias against women, other researchers have found these biases due largely due to incumbency which discriminates against all challengers (Cook, Thomas, and Wilcox 1994; Darcy and Choike 1986). More recently, Gaddie and Bullock (1995) found no bias against women in open

NOTE: We wish to thank the editors and anonymous reviewers for their comments and recommendations on this research. Direct all Correspondence to Ronald Keith Gaddie, Department of Political Science, 205 Dale Hall Tower, The University of Oklahoma, Norman, OK 73019-0535 (INTERNET rkgaddie@ou.edu).

Political Research Quarterly, Vol. 50, No. 2 (June 1997): pp. 459-468 
seat congressional elections. In this article, we extend our previous research on sex in open seats to ascertain whether bias is evident in a littlestudied category of congressional election: the special election. The political dynamics of special elections in the U.S. are compared to previous findings in regularly scheduled open seat contests to determine whether the competitiveness of women in regular open seats carries into special elections. These elections often receive little attention, even from the constituents of the vacated district. Still, while forty-eight elections across fourteen years may seem to be a small population, it is important to consider that special elections constitute less than 1.5 percent of congressional contests between 1981 and 1995, while producing nearly 10 percent of new House members during that period. During this time only 154 members of Congress came to the House by defeating incumbents, while in 2585 instances the incumbent was returned. Of the 508 first-time members of Congress elected between 1981 and 1995, two-thirds were the product of regular open seat contests.

Patterns of female candidate competitiveness are examined in 48 special House elections held from 1981 to 1995. A multivariate model is specified to determine whether a significant sexual bias occurs in special elections, and those results are compared to our previous analysis, expanded to 282 open seat races by the addition of the 1994 elections (Gaddie and Bullock 1995). We then discuss the implications of our findings for understanding female competitiveness in congressional elections.

\section{Special Elections, Open Seats, and Women as Candidates}

Sigelman (1981) argued that special elections were special precisely because they guaranteed sudden, unexpected changes in representation. Although the level of partisan change is not greater in special elections than in regularly occurring open seats, the change in legislators represents a departure from the past. Sigelman (1981) and Studlar and Sigelman (1987) indicated that special election victors tend to win by comfortable margins, although special elections are still more closely contested than the preceding general election. When party change occurred, it usually involved a loss by the incumbent president's party. Studlar and Sigelman (1987) found that special elections were manifestations of the normal partisan forces operating in general elections. None of this work examined the role of candidate sex in these elections.

Should we expect a sexual bias in special elections? Historically, special elections prompted by the death of legislators have prompted female advancement to Congress. A woman typically succeeded her late husband and then quickly retired from electoral politics after finishing his term 
(Bullock and Heys 1972). Having a widow warm the seat allowed potential aspirants to position themselves for a run at the seat in the regular elections. ${ }^{1}$

If, as the literature through the 1980s contended, women confront disadvantages in obtaining and mobilizing the political assets necessary to gain election (Anderson and Thorson 1984), then special elections should contain a bias against women. The season for special elections is short. Many states require that elections be held within a certain period following the vacancy, or at the next available election date. In a compressed campaign season, candidates who hold political office or have access to funding are best positioned to compete: proportionally more of these politicians are men.

Before 1980, most research examining women's political performance ascribed their absence from all levels of public office to a lack of motivation or ambition or to family-related or traditional cultural factors (K. Carroll 1983). Recent research has turned away from cultural and motivational explanations (S. Carroll 1994), and has focused on factors that could affect female electability, such as availability, elite support, and campaign financing (Darcy, Welch, and Clark 1987). ${ }^{2}$ Darcy and Choike's (1986) examination of the impact of legislative turnover on female representation finds the rate of incumbent turnover and the presence of female candidates to be two driving forces behind female representation. The implication is that opportunities for female advancement are blocked not by discrimination but rather by structures that hurt nonincumbents in general. For example, redistricting and the turnover of incumbents have been tied to the influx of women into Congress (Burrell 1994). When the status quo is upset by redistricting or an incumbent's death or resignation, the cues used by voters and politically powerful elites are muted, so that special elections can potentially serve as a vehicle for female political advancement. In order to test for bias in female electoral performance while eliminating the dampening effects of incumbency, we examined several aspects of female representation in open seat elections, including: candidacies and candidate political experience; nominations (winning primaries); financial support; and election results (Gaddie and Bullock 1995). Our research indicated that, in the absence of incumbency, female candidates for Congress tended to be as experienced and well-funded as male candidates. Women

1 Some women who followed their late husbands to Congress remained in office and had careers that approached that of the late spouse, such as Margaret Chase Smith or Corinne "Lindy" Boggs.

${ }^{2}$ An alternative perspective comes from Rosenthal (1995), who finds that women are more likely to have a preference for descriptive representation that can extend to voting behavior. 
were as successful at obtaining nominations and winning elections, and female candidates prevailed under the same circumstances as men. ${ }^{3}$

\section{Data AND Analysis}

From 1981 to 1994, the death, resignation, or incapacitation of members of Congress produced 58 vacancies. Special elections filled 48 of these, and ten were filled by concurrent general elections. Data on special elections were collected from a variety of sources. Vacancies were identified in Congressional Quarterly Weekly Report and special elections that coincided with general elections for the same seat were included in the comparison group of regular open seats; in all but one case the same individual won both elections. ${ }^{4}$ Primary and general election data and candidate backgrounds came from Congressional Quarterly Weekly Report and the Almanac of American Politics. Campaign finance data are from the Federal Election Commission and editions of the Almanac of American Politics.

In only 4 of 48 cases did a widow seek to succeed her spouse. Three of the widows were successful. John Ashbrook's (R-Ohio) widow ran to fill her husband's term, with the promise of retiring. The fact that, subsequent to Ashbrook's death, the district was dismantled to accommodate the loss of seats by Ohio in reapportionment may have contributed to Mrs. Ashbrook's decision, and this factor also probably contributed to the lack of intra-party opposition to her candidacy. Cathy Long (D-La.), similarly held her husband's seat for the balance of his term before retiring. The only widow in our data set to continue in Congress, Sala Burton, served until her own death in early $1987 .{ }^{5}$ The lone losing widow, Kathy MacDonald, lost in a runoff.

When special elections occur, the nominee of the incumbent's party usually wins, and when switches occur it is usually the incumbent president's party that loses. Therefore, we expect that partisans of the incumbent district party would be more prone to seek congressional office than the district's "outs." Because of the short campaign cycle and the abrupt departure of the incumbent, special elections should attract highly experienced candidates, especially from the Democratic party. The Democratic party down-ticket strength is readily evident in the fields of candidates who competed in special elections.

3 The "self-declared" pool of candidates is overwhelmingly male ( 86 percent of 306 candidates). Explaining this discrepancy in the sex of candidates is beyond the scope of this note.

${ }^{4}$ That unique case occurred in 1986 when Neil Abercrombie was elected to fill the last three months of the term of Cecil Heftel, but lost the primary held the same day for the two-year term.

5 Sala Burton died in office and was succeeded in a special election by another woman, Nancy Pelosi (D-CA). 
The disproportionate Democratic advantage in experience indicates that those candidates perceive an advantage to jumping into a special race. Even when confronted with ambitious widows, our limited data indicate that eager professionals will contest a special election. It has been speculated that special elections may attract a far larger number of amateurs than normal open seat races. However, the average number of candidates in special elections (6.38) is slightly less than in regular open seat elections (6.62), and the fields are far more experienced on the Democratic side.

The distribution of electoral experience in special elections follows the patterns observed in the other open seats. Legislators are the most prevalent experienced candidates for both parties, followed by local elected officials and then former members of Congress or statewide officials, who rarely contest these seats. When we examine who wins special elections, the power of political experience once again shows through. Of the 48 new legislators elected in special elections, 33 ( 68.8 percent) held prior elective office.

Women made up a slightly larger share of the candidates in special elections than in other open seat contests. Of the 306 major party candidates we identified, 43 were women ( 14.3 percent) compared to about 12.5 percent of candidates in other open seat contests; this is not a statistically significant difference. Slightly more women than men had elective experience. Although women less often had state legislative experience than their male counterparts (13.7 to 23.5 percent), they more often had local elective experience (18.6 to 12.2 percent). Women were twice as likely as men to have appointive or partisan experience in politics (12.6 to 4.9 percent).

Women were far more successful than men in obtaining nominations in special elections. Of the 43 women who competed in special elections, 18 (4l.8 percent) made it to a general election or runoff; only a quarter of the 243 men were similarly successful. Women in special elections win nomination at a far higher rate than women in open seats. Gaddie and Bullock (1995) found that a slightly higher proportion of women than men succeeded in winning primary nominations for regular open seats; in the special open seats, the female advantage is more pronounced. Female candidates were far more likely to lead an initial primary (37.2 percent of women, 22.1 percent of men).

Of the 18 women who were positioned to win a seat in Congress, 10 succeeded. Three of the new congresswoman were widows, and another was the daughter of the departed member of Congress. ${ }^{6}$ The women who ascended to the House in special elections were politically experienced; 5 had held

${ }^{6}$ Susan Molinari (R-NY) succeeded her father, Representative Guy Molinari, upon his election as borough president of Staten Island. 
elective office, 2 were former party officials, and 1 was a previous Democratic nominee for the U.S. Senate. Three of the 8 losing women had held elective office.

Compared to their male counterparts, women were more likely to secure nomination and to win election. Because of the small number of special elections held, these differences do not always meet conventional standards of statistical significance. However, the results of special elections support our previous findings about women in open seats: disrupting the status quo through redistricting or other episodic events creates opportunities for female advancement.

To understand better the role of sex in special elections, we estimated a multivariate model of open seat and special elections that includes controls for candidate sex. The multivariate model is essentially the same model specified by Gaddie and Bullock (1995) to test for sexual bias in open seat elections, with minor modifications necessary to examine special elections. The multivariate analysis controls for two of established predictors of candidate success-candidate financial quality ${ }^{7}$ and candidate political experience ${ }^{8}-$ for both Democratic and Republican candidates. In order to control for the impact of national political trends, we introduced measures of presidential coattails and presidential popularity. Presidential coattails are evident at virtually every electoral level from the U.S. Senate to state legislative elections, and are controlled for by the GOP presidential vote in the district. In midterm election years the coattails are coded 0 , and dummy variable controls for the presidential election years control for the coattail potential skewedness in the coattail estimate. Coattails measures are not included in the special elections analysis, where by definition they are absent. To tap the electorate's executive evaluation, we do incorporate a measure of presidential popularity into the special election model. ${ }^{9}$

To assess the independent variable of interest (candidate sex), dichotomous variables are included to indicate whether the Democratic or Republican candidate is female. The dependent variable is the percent of the two-party

${ }^{7}$ Candidate financial quality is measured in hundreds of thousands of constant 1994 dollars.

${ }^{8}$ Candidate quality is measured on the Green and Krasno (1988) index of candidate quality, which incorporates professional, celebrity, and elective political experience into one measure.

${ }^{9}$ Presidential popularity is the quarterly Gallup presidential approval score for the month of the election. Presidential approval is coded as the Gallup score for contests during the Reagan and Bush administrations, and (100 - Gallup score) for contests during the Clinton administration. 
vote for the Republican candidate with uncontested seats excluded. OLS regression is used to estimate the relationship between the dependent and independent variables.

The results of the analyses appear in Table 1 . The model produces a good fit to both the open seat and special election data, although differences are evident. Democratic experience is not a significant predictor of special election outcomes, which is contrary both to our observations of regular open seats and to the findings of the regular congressional elections literature (Jacobson 1990) ${ }^{10}$ The magnitude of the spending coefficients is far greater in special elections. Although the relationships are in the same (expected) directions and are highly significant, the ability of candidates to spend money produces larger electoral benefits in special elections.

While a significant impact by sex is not evident for Republican or Democratic candidates, the size of the coefficients and the near significance of the Republican candidate's sex merits further investigation. Republican candidates

$\equiv \mathrm{T}_{\text {ABLE }} 1$

Candidate Sex and Open Seat and Special Elections, 1981-1995

\begin{tabular}{lrrrr}
\hline Variable & \multicolumn{2}{c}{ Open Seats } & \multicolumn{2}{c}{ Special Elections } \\
& $\mathrm{b}$ & $\mathrm{t}$ & $\mathrm{b}$ & $\mathrm{t}$ \\
\hline Constant & 54.62 & & 46.67 & \\
Female Democratic Candidate & 1.07 & .88 & -4.78 & -1.18 \\
Female Republican Candidate & .49 & .30 & -6.03 & -1.33 \\
Democratic Candidate Experience & -1.51 & $-5.40^{* *}$ & -.37 & -.47 \\
Republican Candidate Experience & 1.34 & $5.04^{* *}$ & 1.66 & $2.34^{*}$ \\
Democratic Spending (in \$100,000) & -.68 & $-5.09^{* *}$ & -1.66 & $-2.57^{*}$ \\
Republican Spending (in $\$ 100,000)$ & .88 & $5.68^{* *}$ & 2.18 & $3.25^{*}$ \\
Black Population & -.24 & $-7.31^{* *}$ & -.30 & $-4.28^{* *}$ \\
Hispanic Population & -.16 & $-4.13^{* *}$ & -.23 & $-2.38^{*}$ \\
Presidential Popularity & .05 & .50 & .39 & $1.65+$ \\
Year 1984 & -26.78 & $-4.71^{* *}$ & - & \\
Year 1988 & -26.16 & $-5.14^{* *}$ & - & \\
Year 1992 & -18.57 & $-5.45^{* *}$ & - & \\
Presidential Coattails & .46 & $5.23^{* *}$ & - & \\
$\mathrm{R}^{2}$ & .66 & & .65 & \\
Adjusted-R & .64 & & .57 & \\
$\mathrm{~N}$ & 282 & & 43 & \\
\hline
\end{tabular}

Note: Dependent variable is the Republican candidate's share of the two-party vote. $+\mathrm{p}<.05$, one-tailed test. ${ }^{*} \mathrm{p}<.01$, one-tailed test. ${ }^{* *} \mathrm{p}<.001$, one-tailed test.

${ }^{10}$ Democratic candidates were especially well-experienced in special elections compared to regular open seats, winning and losing Democrats were similarly highly-experienced. 
held the spending advantage in 20 of the 43 cases ( 46.5 percent) for which we have complete data, but Republican women held a spending advantage in just 2 of 8 cases. Among Democrats, men held a spending advantage in 16 of 33 cases ( 48.4 percent) while Democratic women were the top spenders in 7 of 10 cases. The average expenditure of a Democratic woman was twice the average of her opponent, and almost \$125,000 (constant 1994 dollars) more than the average expenditures of male Democrats. Average expenditures for Republican men and women wére not statistically distinguishable, but the average male Republican spent slightly more that his opponent, while the average Republican female was outspent by almost $\$ 200,000$. Implying sexual bias based on so few cases is suspect; however, this discrepancy indicates a partisan difference that favored the election of Democratic women.

\section{Conclusions}

Special elections are subject to many of the same influences as other open seat contests. In many ways these contests illustrate the underlying contours of open seats, and closely resemble the findings from research on regularly scheduled elections. Sigelman (1981) argued even though special elections did not produce a great deal of partisan change, these elections should not be considered unimportant. Special elections provide sudden, dramatic opportunities for change which makes them interesting. Even though the media and voters often deem these races to be unimportant or uninteresting, they attract fields of candidates that are as large and as broadly experienced as in the most hotly contested, high-profile open seat contests. The impact of special elections in creating opportunities for women supports the spirit of Sigelman's assessment; however, the level of female candidate emergence at the initiation of the campaign indicates that these opportunities are not capitalized on by women in large numbers. Women still run in far fewer numbers than men; only one in six declared candidates is female. The discrepancies observed across open seat and special elections are not statistically discernable, indicating that whatever factors constrain the emergence of women as candidates in regular open seat elections are apparently at work when sudden vacancies occur.

The popular perception of special elections is that, because they occur suddenly and in an abbreviated campaign season, they are the province of experienced officeholders and political insiders who can bring together the assets needed to conduct an intensive, short campaign. Our research indicates no bias against women in this respect. Women who run in special open seat elections are as successful or more successful than their male counterparts. They more often find themselves positioned to compete in runoffs or general elections: they finish higher in primaries; and they generally have 
more success winning, relative to their numbers. There is some indication that Republican women ran under more restrictive conditions and performed poorly compared to both Democratic women and Republican men. Finally, we can conclude that female success does not appear to be tied to a morbid form of coattails. While historically the path of women to Congress through special elections might have been described as a widows' walk, this is no longer the case. The women who contest and win special elections are experienced, well-financed politicians able to marshal support for their candidacies. The same effects we observed due to redistricting and retirement in "normal" open seat campaigns are apparent in special elections.

\section{REFERENCES}

Anderson, Kristi, and Stuart J. Thorson. 1984. "Congressional Turnover and the Election of Women." Western Political Quarterly 37: 143-56.

Barone, Michael, and Grant Ujifusa. 1983-1995 inclusive. The Almanac of American Politics. Washington, DC: National Journal.

Bullock, Charles S., III, and Patricia Lee Findley Heys. 1972. "Recruitment of Women for Congress." Western Political Quarterly 25: 416-23.

Burrell, Barbara C. 1994. A Woman's Place is in the House. Ann Arbor: University of Michigan Press.

Carroll, Kathleen M. 1983. "The Age Difference Between Men and Women Politicians." Social Science Quarterly, 64: 332-39.

Carroll, Susan J. 1994. Women as Candidates in American Politics. Bloomington: Indiana University Press.

Cook, Elizabeth Adell, Sue Thomas, and Clyde Wilcox, eds. 1994. The Year of the Woman: Myths and Realities. Boulder, CO: Westview Press.

Darcy, R., and James R. Choike. 1986. "A Formal Analysis of Legislative Turnover: Women Candidates and Legislative Representation." American Journal of Political Science 30: 237-55.

Darcy, R., Susan Welch, and Janet Clark. 1987. Women, Elections, and Representation. Boulder, CO: Westview Press.

Gaddie, Ronald Keith, and Charles S. Bullock, III . 1995. "Congressional Elections and the Year of the Woman: Structural and Elite Influences on Female Candidacies." Social Science Quarterly 76: 749-62.

Green, Donald Philip, and Jonathan S. Krasno. 1988. "Salvation for the Spendthrift Incumbent: Reestimating the Effects of Campaign Spending in House Elections." American Journal of Political Science, 32: 884-907.

Jacobson. Gary C. 1990. The Electoral Origins of Divided Government. Boulder, CO: Westview Press.

Rosenthal, Cindy Simon. 1995. "The Role of Gender in Descriptive Representation." Political Research Quarterly 48: 599-611. 
Sigelman, Lee. 1981. "Special Elections to the U.S. House: Some Descriptive Generalizations." Legislative Studies Quarterly 6: 577-88.

Studlar, Donley T., and Lee Sigelman. 1987. "Special Elections: A Comparative Perspective." British Journal of Political Science 17: 247-56.

Thomas, Sue. 1994. How Women Legislate. New York: Oxford University Press. 